\title{
Analysis of Bacterial Community Structure and Diversity in Traditional Gold Mining Waste Disposal Site by Using a Metabarcoding Approach
}

\author{
Fatimawali $^{1, *}$, B J Kepel ${ }^{2}$, M A Gani ${ }^{1}$ and T E Tallei ${ }^{3}$ \\ ${ }^{1}$ Pharmacy Study Program, Faculty of Mathematics, Sam Ratulangi University, North Sulawesi, Indonesia \\ ${ }^{2}$ Department of Chemistry, Faculty of Medicine, Sam Ratulangi University, North Sulawesi, Indonesia \\ ${ }^{3}$ Department of Biology, Faculty of Mathematics and Natural Sciences, Sam Ratulangi University \\ *Corresponding author. Email: fatimawali12@gmail.com
}

\begin{abstract}
The purpose of this study was to evaluate the effect of mercury contamination on bacterial community and structure in the contaminated soil at the mining waste disposal site (sample1) compare with uncontaminated soil (sample2). Mercury level was analyzed using the CVAFS method, and analysis of bacterial composition was carried out using metagenomic data generated from the V3-V4 region of 16S rRNA obtained from paired-end Illumina MiSeq reads. The results showed that the mercury level in sample 1 and 2 were 230 and $1.5 \mathrm{mg} / \mathrm{kg}$, respectively. Metagenomic analysis showed that there were 57,031 reads in sample 1, consisting of 16 phyla, and 53,525 reads in sample 2 , consisting of 15 phyla. Firmicutes was the most abundant phylum in sample 1, followed by Proteobacteria, Planctomycetes, Acidobacteria, Actinobacteria, and Chlorophlexi. Sample 2 was dominated by Firmicutes, followed by Proteobacteria and Planctomycetes. Bacilli was the most abundant class in sample 1, followed by Gammaproteobacteria and Planctomycetia. Bacilli was also the most abundant class in sample 2, followed by Clostridia. The predominating families in both samples were Bacillaceae. Aeromonadaceae was a large family after Bacillaceae in sample 1, and Peptostreptococcaceae in sample 2. This study provides an understanding of the microbial community structure in an area that is highly contaminated with mercury to open insight into the potential of these bacteria for mercury bioremediation.
\end{abstract}

Keywords: Metabarcoding, Bacteria community, Mercury level, Gold mining

\section{INTRODUCTION}

The presence of mercury in the soil has been an environmental concern and social problem. Mercury is a very toxic element, even though it is present in very little concentration in the body. The mercury biogeochemical cycle in the environment plays a role in regulating mercury toxicity, where the process of direct or indirect methylation of mercury ions $\left(\mathrm{Hg}^{2+}\right)$ or degradation (demethylation) of methylmercury is an important key to mercury detoxification, both in the mechanism of transformation by microorganisms and by the abiotic environment [1]. Organic mercury will degrade to form mercury ions $\left(\mathrm{Hg}^{2+}\right)$ by the organomercury lyase enzyme, and then $\left(\mathrm{Hg}^{2+}\right)$ this will be detoxified by mercury reductase to volatile $\mathrm{Hg}^{0}$ [2]

Strains of mercury-resistant bacteria have a set of genes called mer operons, which are usually found on plasmids [3,4]. The mechanism of detoxification of mercury by these genes involves the merA gene, which encodes for the protein MerB enzyme (organomercury lyase) which catalyzes the termination of the $\mathrm{C}-\mathrm{Hg}$ bond in organic mercury [5,6] to produce reduced carbon and mercury ions [3]. The cleavage of $\mathrm{C}-\mathrm{Hg}$ bonds releases $\mathrm{Hg}^{2+}$ ions, which are usually followed by the reduction of these ions to $\mathrm{Hg}^{0}$ by the MerA enzyme encoded by the merA gene. Both of these stages are mechanism owned by broad-spectrum mercury resistance bacteria [7].

One approach that has been developed in recent years to identify bacteria found in the environment is metabarcoding which involves the use of the 16S rRNA gene as a molecular marker to study differences in bacterial composition and structure [8]. This approach is more reliable than traditional methods that involve planting and isolating bacteria from the environment, 
which often causes many bacteria that cannot be identified because they cannot grow on the culture media used $[3,4,5,6]$. The metabarcoding approach can be used to identify bacterial and archaebacterial species, so this kind of analysis has become the de facto standard for prokaryotic taxonomy [9].

Research on comparing bacterial community in mercury-polluted and non-polluted sites were conducted to understand the shifting of the microbial structure and diversity, which has now been facilitated to quick identification soil microbiome using the metabarcoding technique. This research aimed at determining the impact of mercury contamination on the bacterial community in the traditional gold mining waste disposal site. Mercury analysis was carried out using the CVAFS method. Analysis of bacterial communities and structure was carried out based on the results of metabarcoding of V3-V4 16S rRNA regions generated by paired-end Illumina MiSeq reads [8].

\section{MATERIAL AND METHODS}

\subsection{Study Area and Samples Collection}

Soil samples North Tanoyan Village, Bolaang Mongondow Regency, North Sulawesi, where the local community uses metal mercury to extract gold from ore. Sample 1 was obtained from the mine waste disposal hole, and sample 2 was taken from the site about 50 meters from the location of sample 1 . The samples to be evaluated were stored in sterile polyethylene tubes and taken to the laboratory using a cool box for further analysis

\subsection{Mercury Level Analysis of the Samples}

The analysis began with extracting $0.20 \mathrm{~g}$ of each soil sample with $10 \mathrm{ml}$ of mixed solution $(90 \mathrm{~mol} / \mathrm{L}$ $\mathrm{HNO}_{3}$ and $4 \mathrm{~mol} / \mathrm{L} \mathrm{HCl}$ ) in a Teflon tube at $95^{\circ} \mathrm{C}$ for two hours. The total level of $\mathrm{Hg}$ contained in these extracts was determined using cold vapor atomic fluorescence spectrometry (CVAFS) (USEPA-3050-B (1996) and USEPA 245.7 (2005).

\subsection{Metagenomic Preparation Bioinformatics Pipelines} and

DNA extraction, PCR amplification, and high throughput sequencing, as well as data processing, was conducted following Tellei et al. [8]. ZymoBiomics DNA Mini Kit (Zymo Research) was used to extract the genomic DNAs (gDNAs) of the bacteria according to protocol. MyTaq ${ }^{\text {TM }}$ HS Red Mix (Bioline, BIO-25044) was used to amplify the hypervariable V3-V4 regions of 16S rRNA in Agilent SureCycler 8800 Thermal Cycler. The following is the condition of PCR reaction: initial denaturation at $95^{\circ} \mathrm{C}$ for $3 \mathrm{~min}$, followed by 35 cycles of denaturation at $95^{\circ} \mathrm{C}$ for $15 \mathrm{sec}$, annealing at $52^{\circ} \mathrm{C}$ for 30 sec, and extension at $72^{\circ} \mathrm{C}$ for $45 \mathrm{sec}$, then followed by final extension at $72^{\circ} \mathrm{C}$ for $3 \mathrm{~min}$. Preparation of $16 \mathrm{~S}$ rRNA libraries and bioinformatics analysis were performed by the sequencing services provider.

\section{RESULT AND DISCUSSION}

\subsection{Mercury Levels of the Samples}

Mercury concentrations in both soil samples were analyzed using CVAFS, which is commonly used because of its sensitivity to detect low heavy metal content ${ }^{1}$. Sample 1 contained a much higher concentration of mercury $(230 \mathrm{mg} / \mathrm{kg})$ compared to sample $2(1.50 \mathrm{mg} / \mathrm{kg})$. The location of sample 2 was 50 $\mathrm{m}$ away from the location of sample 1 . The critical concentration of mercury in the environment is around $0.3-0.5 \mathrm{ppm}$ [10], so the mercury level in location 2 is still above the critical threshold. Vishnivetskaya et al. 2011 reported that as the downstream distance from the industrial facility increased, inorganic mercury levels also decreased while $\mathrm{MeHg}$ levels increased. $\mathrm{MeHg}$ is a volatile compound that cannot be detected in this study [11]. Due to the safety factor, $75 \mathrm{ppm}$ of mercury in the soil was suggested as an acceptable limit [12].

\subsection{Bacterial Composition and Structure}

Various types of bacteria were identified in both locations, as seen in Figures 1 and 2. Sample 1 produced 57.031 reads while there were 53.525 reads in sample 2 . Firmicutes $(90.07 \%)$ were the most abundant phylum in sample 2 with low $\mathrm{Hg}$ levels, while this phylum reduced in number to $49.78 \%$ in sample 1 , which had a high mercury level reported that the total level of $\mathrm{Hg}$ in soil has a positive correlation with the relative abundance of Firmicutes and Bacteroidetes both in dry soil and rice fields. Proteobacteria and Planctomycetes were detected in sample 2, 6.57, and $0.41 \%$, respectively. However, the prevalence of these two phyla in sample 1 was higher, 24.38 , and $15.30 \%$, respectively. These results indicate that both phyla increased in $\mathrm{Hg}$-contaminated environments. These results suggest that $\mathrm{Hg}$ contamination increased phylum prevalence in the soil, especially Planctomycetes and Proteobacteria, but decrease the prevalence of Firmicutes. There were 15 phyla in sample 2, while 16 phyla were found in sample 1.

Chen et al. 2018 reported that Proteobacteria were the most abundant phyla $(61.4 \%)$ in samples with mercury levels above the critical threshold, while the second dominant phylum is Bacteroidetes, with a prevalence of $24.06 \%$ [14]. In the sample with low mercury levels, the second most dominant phylum was Acidobacteria, with a prevalence of $28.61 \%$. An 
interesting fact to know is that there were three bacterial phyla found in sample 1, namely Acidobacteria (3.35\%), Actinobacteria (2.45\%), and Chlorophlexi of $2 \%$ but reduced in number in sample $2(0.03,0.4$, and $0.12 \%$, respectively). The results obtained are not in accordance with Chen et al., 2018 [14], where in sample with low mercury level, the second most dominant phylum was Acidobacteria with a prevalence of $28.61 \%$. Rasmussen et al. 2008 reported that a partial sequence of the merA gene was found in Alpha-, Betaproteobacteria, and Actinobacteria but not in Bacteroidetes and Firmicutes [15].

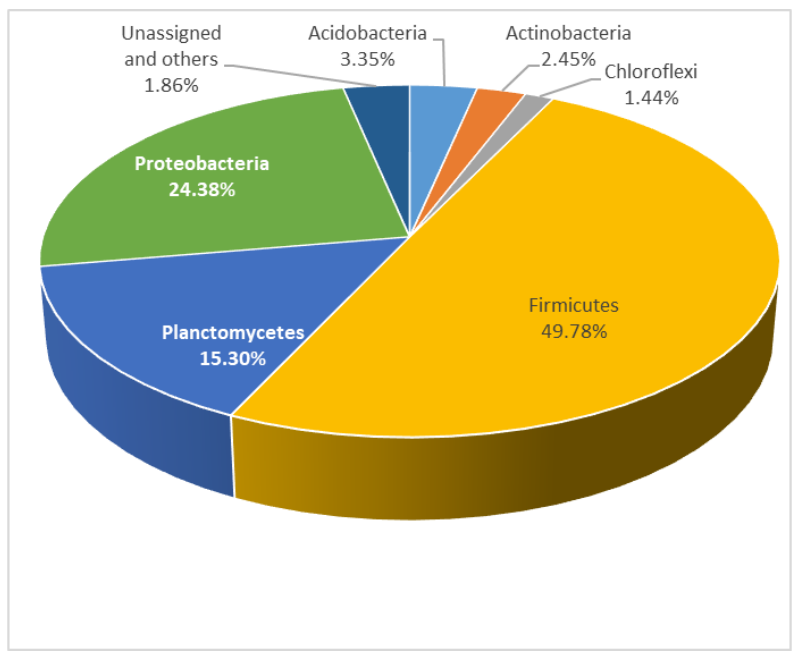

Figure 1. The percentage of phyla dominance in sample 1

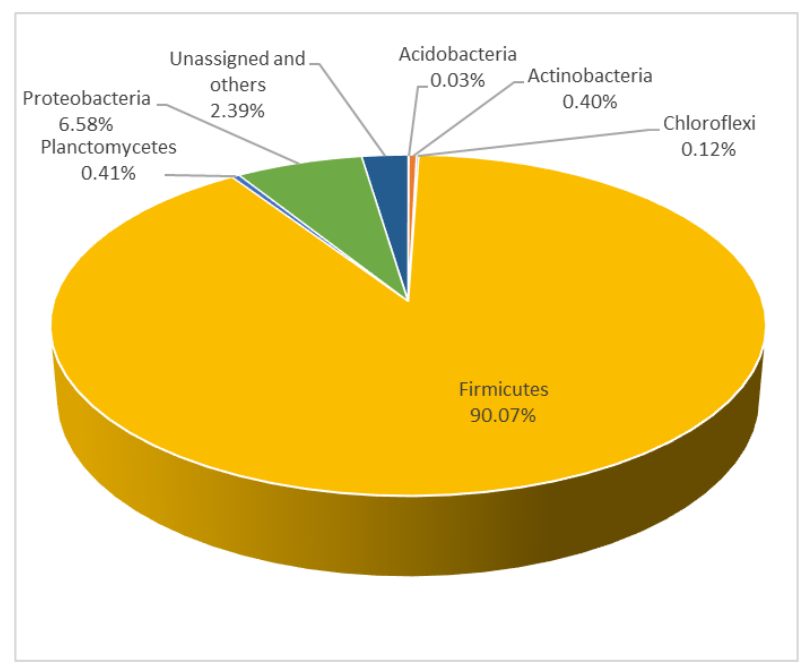

Figure 2. The percentage of phyla dominance in sample 2
In the bacterial class, Bacilli was the most abundant in sample 1 (45.41\%), followed by the Gammaproteobacteria class of $22.94 \%$, whereas in sample 2, the most abundant class was Bacilli by $56.98 \%$, Clostridia by $33.10 \%$ and Gammaproteobacteria $6.06 \%$. This result shows that Bacilli and Gammaproteobacteria can survive on soils with high mercury levels up to $230 \mathrm{ppm}$, including high mercury resistant bacteria. Previous studies reported that some genera and species belonging to this class were found in contaminated-mercury areas and detected to have a merA gene[16, 17, 18, 19, 20]. Several Gammaproteobacteria were able to reduce $\mathrm{Hg}$ (II) to volatile $\mathrm{Hg}(0)$ [21].

At the family level, sample 1 was dominated by Bacillaceae $(28.75 \%)$, followed by Aeromonadaceae $(20.60 \%)$, while in sample 2, the dominating families were Bacillaceae $(28.90 \%)$ and Peptosteptococcaceae (24.33\%). Bacteria in Bacillaceae are Gram-positive, aerobic, or facultative anaerobic, rod-shaped, and chemoorganothropic [22]. Peptostreptococcaceae was also identified in an individual using amalgam dental filling [23]. Bacillus thuringiensis was found in the teeth plaque of individuals with amalgam dental filing [24].

\subsection{Bacterial Diversity of The Pyla}

Alpha diversity of bacterial communities found in samples A and B is presented in Table 1. According to the Dominance (D) index, which ranges from 0 to 1 , the phyla diversity in sample 2 is higher than in sample 1 . The $\mathrm{D}$ indices of both samples are significantly different at $\mathrm{p}<.05$. The evenness index ( $\left.\mathrm{J}^{\prime}\right)$ ranges from 0 to 1 . The lower the value of J', the less evenness in the community between the phyla, therefor there is a presence of a dominant phylum. The value of $\mathrm{J}$ ' in sample 2 was lower than in sample 1, although both samples showed lower J' value. This indicates that there was phyla dominance in both samples because taxa are not evenly distributed $[25,26,27$. The $J$ ' value in sample 2 was very low $(0.102 \pm 0.0000)$ because of the dominance of phylum Firmicutes $(90 \%$ of the whole phyla). This sample had a low mercury level (1.5 $\mathrm{mg} / \mathrm{kg})$, although it was still above the critical threshold.

The Margalef index has the following criteria for the richness of the taxa: $\mathrm{R}<2.5$ ( low), $2.5>\mathrm{R}<4$ (moderate), and $\mathrm{R}>4$ (high). Based on these criteria, the taxa richness in both samples was low. High species richness

Table 1. Alpha Diversity of the Bacterial Phyla in Sample 1 and 2

\begin{tabular}{llll}
\hline Alpha Diversity & Sample 1 & Sample 2 & One Way Anova \\
\hline Dominance D & $0.333 \pm 0.003$ & $0.816 \pm 0.004$ & significantly different at $\mathrm{p}<.05$. \\
Evenness e $^{\mathrm{H} / \mathrm{S}}\left(\mathrm{J}^{\prime}\right)$ & $0.254 \pm 0.002$ & $0.102 \pm 0.000$ & significantly different at $\mathrm{p}<.05$. \\
Margalef & $1.370 \pm 0.000$ & $1.286 \pm 0.000$ & significantly different at $\mathrm{p}<.05$. \\
\hline
\end{tabular}


signifies high stability in an ecosystem, allowing the ecosystem to be more resistant to natural and anthropogenic disturbances [28].

\section{CONCLUSION}

This study concluded that higher mercury levels in the soil reduced the diversity of the phyla, although the evenness was slightly higher than in the lower mercury level. The dominating phylum in both locations was Firmicutes, although the prevalence of this phylum decreased in a higher level of mercury. Bacilli dominated the bacterial class in both samples. Bacillaceae and Aeromonadaceae were predominating families in soil with a higher level of mercury, while Bacillaceae and Peptosteptococcaceae were predominating in soil with a lower level of mercury. As a suggestion, this research can be continued by isolating the mercury resistance bacteria contained in the study area for use in the mercury bioremediation process.

\section{ACKNOWLEDGMENTS}

This work was financed by Research Council and Community Service, Ministry of research, technology and Higher Education, Republic of Indonesia, through basic excellence research schemes (PDUPT) fiscal year 2019 (Grant Number:156/UN12.13/LT/2019).

\section{REFERENCES}

[1] Barkay $\mathrm{T}$ and Irene Wagner-Dobler 2005 Microbial Transformation of Mercury: Potentials, Challenges, and Achievements in Controlling Mercury Toxicity in the Environment, Department of Biochemistry and Microbiology Cook College, Rutgers University New Brunswick, New Jersey 08901. Advances in Applied Microbiology.

[2] Gupta A, Phung LT, Chakravarty L, Silver S 1999 J Bacteriol, 181(22): 7080-7086.

[3] Benison GC, Di Lello P, Shokes JE, Cosper NJ, Scott RA, Legault P, Omichinski JG. 2004. A stable mercury-containing complex of the organomercurial lyase MerB: catalysis, product release, and direct transfer to MerA. Biochemistry, 43(26): 8333-45.

[4] Fatimawali, Kepel B, Tallei T E 2015 Indonesian Journal of Pharmacy, ISSN-p : 23389427, vol. 26, no. 3.

[5] Kepel B J, Fatimawali, Irawan Yusuf, Rosdiana Natsir, Fatmawati Badaruddin 2012 Jurnal Kedokteran Yarsi. 20(2): 069-080

[6] Omichinski 2007 Toward Methylmercury Bioremediation. Science 317: 205-206

[7] Barkay T, Miller S M, Summers A O 2003 Bacterial mercury resistance from atoms to ecosystems, Department of Biochemistry and Microbiology, Cook College, Rutgers University,
New Brusnwick, USA, FEMS Microbiology Reviews, Elsevier.

[8] Tallei T E, Fatimawali and Pelealu J J 2019 The data on metagenomic profile of bacterial diversity changes in the different concentration of fermented romaine lettuce brine. Data in Brief 25:104190

[9] Bukin, Y S, Galachyants Y P, Morozov I V, Bukin S V, Zakharenko A S, \& Zemskaya, T I 2019 Scientific data 6, 190007. doi:10.1038/sdata.2019.7

[10] Mirdat, Patádungan Y S, Isrun 2013 e-J. Agrotekbis 1 (2) : 127-134

[11] Vishnivetskaya, T A, Mosher, J J, Palumbo A V, Yang Z K, Podar M, Brown S D, Elias D A 2011 Applied and Environmental Microbiology, 77(1), 302-311. https://doi.org/10.1128/AEM.01715-10

[12] Revis N W, Osborne T R, Holdsworth G, Hadden C 1990 Mercury in soil: A method for assessing acceptable limits. Arch Environ. Contam Toxicol., 19; 221-226.

[13] Liu Y R, Delgado-Baquerizo M, Bi L, Zhu J, \& He J Z 2018 Microbiome, 6(1). https://doi.org/10.1186/s40168-018-0572-7

[14] Chen Y, Jiang Y, Huang H, Mou L, Ru J, Zhao J. $\&$ Xiao S 2018. Science of the Total Environment, 637-638, 1400-1412. https://doi.org/10.1016/j.scitotenv.2018.05.109

[15] Rasmussen L D, Zawadsky C, Binnerup S J, Øregaard G, Sørensen S J, and Kroer N 2008 Applied And Environmental Microbiology, p. 3795-3803 Vol. 74, No. 12

[16] Narita M, Matsui K, Huang C C, Kawabata Z, \& Endo G 2004 FEMS Microbiology Ecology, 48(1), 47-55. https://doi.org/10.1016/j.femsec.2003.12.011

[17] Medina J A C, Farias J E, Cruz Hernández A, Martinez R G, Valdes S S, Silva G H, CamposGuillen J 2013 Geomicrobiology Journal, 30(5), 454-461.

https://doi.org/10.1080/01490451.2012.705229

[18] Giri S, Dash H R, Das S 2014 Mercury resistant bacterial population and characterization of bacillus sp., isolated from sediment of solid waste discharged point of steel industry. National Academy Science Letters, 37(3), 237-243. https://doi.org/10.1007/s40009-014-0229-4

[19] Matsui K, Yoshinami S, Narita M, Chien M F, Phung L T, Silver S, Endo G 2016 FEMS Microbiology Letters, 363(5). https://doi.org/10.1093/femsle/fnw013

[20] Fatimawali, Billy K, Trina T 2017 Bioscience Research 14(4): 1253-1260

[21] Møller, A K, Barkay, T, Al-Soud, W A, Sørensen, S J, Skov H, \& Kroer N 2011 FEMS Microbiology Ecology, 75(3), 390-401. https://doi.org/10.1111/j.15746941.2010.01016.x

[22] Mandic-Mulec I, Stefanic P, van Elsas J D 2015 Microbiology Spectrum, 3(2). 
https://doi.org/10.1128/microbiolspec.tbs-0017-

$\underline{2013}$

[23] Okayanti, N M, Fatimawali, Tallei T E 2017 Jurnal Ilmiah Farmasi Pharmacon vol 6, 4;207217

[24] Tanumihardja A N, Billy Kepel, Widdhi Bodhi 2017 Jurnal e-Biomedik (eBm), Volume 5, 2

[25] Koneri R, Nangoy M J, Saroyo, Tallei T E 2017 Bioscience Research, 14(1), 01-08

[26] Tallei T E, Saroyo, Tallei V R 2018 Bioscience Research 15(1): 443-452

[27] Fatimawali, Kepel B J, Gani M A, Tallei T E 2020 International Journal of Microbiology Volume 2020. Article ID 1858732 https://doi.org/10.1155/2020/1858732

[28] Schwartz M W, Brigham C A, Hoeksema J D, Lyons K G, Mills, M H, van Mantgem P J 2000 Linking biodiversity to ecosystem function: implications for conservation ecology, Oecologia, 122: 297-305. 